\title{
Time-course and levels of apoptosis in various tissues of black tiger shrimp Penaeus monodon infected with white-spot syndrome virus
}

\author{
Kanokpan Wongprasert ${ }^{1}$, Kornnika Khanobdee ${ }^{2}$, Supatra Somapa Glunukarn ${ }^{1}$, \\ Prasert Meeratana ${ }^{3}$, Boonsirm Withyachumnarnkul ${ }^{1,4, *}$
}

\author{
${ }^{1}$ Department of Anatomy, Faculty of Science, Mahidol University, Rama 6 Road, Bangkok 10400, Thailand \\ ${ }^{2}$ Neurobehavioral Biology Center, Institute of Science and Technology for Research and Development, Mahidol University \\ at Salaya, Nakhornpatom, Thailand \\ ${ }^{3}$ Department of Medical Science, Faculty of Science, Burapha University, Chonburi, Thailand \\ ${ }^{4}$ Centex Shrimp, Faculty of Science, Mahidol University, Rama 6 Road, Bangkok 10400, Thailand
}

\begin{abstract}
This study focused on apoptosis in various tissues of the black tiger shrimp Penaeus monodon following white spot syndrome virus (WSSV) injection. The study included: (1) light microscopy (LM) and transmission electron microscopy (TEM) of various tissues; (2) fluorescent LM of nuclear DNA by staining with 4,6-diamidine-2-phenyl indole dihydrochloride (DAPI) and TdTmediated dUTP nick-end labelling (TUNEL) techniques; and (3) determination of caspase-3 activity. Juvenile $P$. monodon were injected with WSSV, and several tissues of ectodermal and mesodermal origin were studied at different intervals after injection. The total haemocyte count had decreased to one-tenth of its original level $60 \mathrm{~h}$ after WSSV injection. By LM, extensive destruction by WSSV was observed in the stomach epithelium, gills, hematopoietic tissue, hemocytes and the heart, but the most severely affected tissue was the subcuticular epithelium. TEM revealed that at $6 \mathrm{~h}$ post-injection (p.i.) the chromatin of infected nuclei was marginated, and by $24 \mathrm{~h}$ p.i. the nuclei were filled with enveloped and non-enveloped WSSV virions. At later stages of the infection, the nucleus extruded WSSV particles. Chromatin margination and nuclear condensation and fragmentation (i.e. signs of apoptosis) were observed as early as $6 \mathrm{~h}$ p.i. in all affected tissues, but occurred in cells without WSSV virions rather than in cells with virions. The occurrence of apoptosis was supported by data obtained using TUNEL and by DAPI-staining and progressed from 6 to $60 \mathrm{~h}$ p.i. In addition, caspase- 3 activity in WSSV-infected shrimp was about 6 -fold higher than that in uninfected shrimp. The data strongly suggests that apoptosis occurs following WSSV infection in P. monodon, but the extent to which it contributes to shrimp mortality requires further investigation.
\end{abstract}

KEY WORDS: Apoptosis $\cdot$ WSSV $\cdot$ TUNEL $\cdot$ DAPI $\cdot$ Penaeus monodon $\cdot$ White-spot disease $\cdot$ Caspase-3

Resale or republication not permitted without written consent of the publisher

\section{INTRODUCTION}

Outbreaks of white spot disease (WSD) in cultured penaeid shrimp infected with white-spot syndrome virus (WSSV) have resulted in mass mortality and serious economic loss worldwide (for review see Flegel 2001). It has been suggested that apoptosis induced by WSSV may be a part of the pathophysiology leading to shrimp death (Flegel \& Pasharawipas 1998, Flegel
2001), as has been shown in Penaeus monodon infected with yellow-head virus (Khanobdee et al. 2002). As shrimp lack a humoral immune response, apoptosis may be a primitive viral defence response and provide a mechanism for preventing viral replication in host cells. Recently, Sahtout et al. (2001) reported TdTmediated dUTP nick-end labelling (TUNEL)-positive cells in various tissues of naturally WSSV-infected $P$. monodon. In their report, shrimp with gross signs of 
WSD contained up to $40 \%$ apoptotic cells and it was suggested that apoptosis might be implicated in shrimp death. As cell death is also caused by necrosis, it is yet not clear whether the main event leading to cell death in WSSV-infected shrimp is apoptosis or necrosis. Moreover, in naturally infected shrimp, it is not possible to determine how long they have been infected with WSSV and how soon after infection apoptosis occurs. To obtain this information, we infected $P$. monodon experimentally with WSSV and monitored the progression of necrosis and apoptosis by morphological and biochemical methods.

\section{MATERIALS AND METHODS}

Healthy juvenile Penaeus monodon, of 8 to $12 \mathrm{~g}$ body weight (BW), were collected from a commercial farm and confirmed to be WSSV-negative by polymerase chain reaction (PCR) (Wongteerasapaya et al. 1995). Shrimp were maintained at $25^{\circ} \mathrm{C}$ in circular concrete tanks containing $1.8 \mathrm{t}$ of brackish water (10 ppt) with adequate aeration to ensure a level of dissolved oxygen above $5 \mathrm{ppm}$. The shrimp were fed with commercial feed pellets at $3 \%$ BW daily and allowed to acclimate for $5 \mathrm{~d}$ before experiments began. The shrimp were divided into 2 groups of 300 shrimp each. In the control group, each shrimp was injected with $0.1 \mathrm{ml}$ lobster haemolymph buffer (LHB) (Paterson \& Stewart 1974) while each shrimp in the infected group was injected intramuscularly with $0.1 \mathrm{ml}$ WSSV extract in LHB.

A crude extract of WSSV was prepared from haemolymph of moribund shrimp obtained from a commercial rearing pond experiencing a WSD outbreak. Haemolymph was withdrawn from the ventral sinus, diluted 1:100 with $\mathrm{LHB}$, and kept at $-20^{\circ} \mathrm{C}$ until used. After injection of the virus solution, 20 shrimp from each group were randomly sampled at 0, 6, 12, 24, 36, 48 and $60 \mathrm{~h}$ post-injection (p.i.), and $0.1 \mathrm{ml}$ of haemolymph was withdrawn from the ventral sinus by inserting a 26-gauge needle attached to a $1 \mathrm{ml}$ syringe containing $0.1 \mathrm{ml}$ of $10 \%$ formalin in $0.5 \% \mathrm{NaCl}$ solution. A small fraction $(\sim 0.01 \mathrm{ml})$ of this fixed haemolymph was placed in a haemocytometer and the total number of haemocytes was counted. The remainder was smeared onto a clean glass slide, air-dried, washed once with 4, 6 diamidine-2phenyllindole dihydrochloride (DAPI) working solution $\left(1 \mu \mathrm{g} \mathrm{ml}^{-1}\right)$, and then stained with DAPI working solution for $15 \mathrm{~min}$ at $37^{\circ} \mathrm{C}$. The solution was discarded and cells were washed with methanol before mounting with anti-fade solution and examining by fluorescent light microscope (LM); 1000 cells were counted and scored for condensed and fragmented nuclei.

After haemolymph withdrawal and prior to fixation (see next paragraph), small fragments of subcuticular epidermis were biopsied from the live shrimp and fixed in $2.5 \%$ glutaraldehyde in $0.1 \mathrm{M}$ cacodylate buffer for $2 \mathrm{~h}$. The tissues were washed in $0.1 \mathrm{M}$ cacodylate buffer and post-fixed in $1 \%$ osmium tetroxide, dehydrated and embedded in Araldite-502 resin. Semi-thin sections were cut at $1 \mu \mathrm{m}$ thickness and stained with toluidine blue in $1 \%$ borax. Ultrathin sections were collected on copper grids, and stained with uranyl acetate and lead citrate for examination with a Hitachi H-300 transmission electron microscope (TEM).

After haemolymph withdrawal and sampling for TEM, the shrimp were perfused and fixed in Davidson's fixative for paraffin sectioning according to the methods described by Lightner (1996). Sections were stained with hematoxylin and eosin (H\&E) and by TUNEL. For TUNEL, the paraffin sections were deparaffinized and rehydrated. The tissues were permeabilized by incubation in $20 \mu \mathrm{g} \mathrm{ml}^{-1}$ Proteinase-K for $15 \mathrm{~min}$ at room temperature and washed in phosphatebuffered saline (PBS) for $15 \mathrm{~min}$. The tissues were then covered with $100 \mu \mathrm{l}$ of equilibration buffer for $10 \mathrm{~min}$, followed by $50 \mu \mathrm{l}$ of TUNEL reaction mixture (containing equilibration buffer, nucleotide mix and TdT enzyme) for $60 \mathrm{~min}$ at $37^{\circ} \mathrm{C}$. The reaction was terminated by washing the samples in $2 \times$ saline sodium citrate for $15 \mathrm{~min}$ at room temperature and then $30 \mathrm{~min}$ 3 times with PBS. The tissues were then counterstained with propidium iodine (PI) for $15 \mathrm{~min}$ in the dark, washed in de-ionized water $(3 \times 5 \mathrm{~min})$ and mounted with 1 drop of anti-fade solution (Vectashield H-100, Vecta Laboratories). TUNEL-positive cells (green fluorescence) were observed by fluorescent LM; 500 cells were randomly counted and scored for TUNEL-positive nuclei. The results were expressed as percentage of TUNEL-positive cells in the total cell count averaged from 3 independent slides.

At 36 h p.i., 5 shrimp per group were used to determine caspase-3 activity. Subcuticular epithelium from the carapace was dissected, placed on ice and sonicated in lysis buffer (25 mM HEPES pH 7.5, $5 \mathrm{mM}$ $\mathrm{MgCl}_{2}, 5 \mathrm{mM}$ EDTA, $5 \mathrm{mM}$ dithiothreitol (DTT), $2 \mathrm{mM}$ phenylmethylsulphonyl fluoride, $10 \mu \mathrm{g} \mathrm{ml}^{-1}$ Pepstatin A, $10 \mu \mathrm{g} \mathrm{ml}^{-1}$ leupeptin). The protein concentration of each lysate was determined (Bradford 1976) and adjusted to $100 \mu \mathrm{g}$ protein, and the lysates were incubated at $37^{\circ} \mathrm{C}$ for $30 \mathrm{~min}$ in $160 \mu$ l caspase assay buffer (10 $\mu \mathrm{l}$ dimethylsulphoxide, $50 \mu \mathrm{l}$ of $100 \mathrm{mM}$ DTT and deionized water to a final volume of $490 \mu \mathrm{l}$ ). Then, $10 \mu \mathrm{l}$ of $2.5 \mathrm{mM}$ CPP32 substrate was added to each tube and the mixture was incubated at $37^{\circ} \mathrm{C}$ for $60 \mathrm{~min}$. The resulting fluorescence was monitored using a spectrofluorometer (Jasco FP-777) at an excitation wavelength of $360 \mathrm{~nm}$ and emission wavelength of $460 \mathrm{~nm}$. The assay was performed in duplicate and blanks were 
processed using lysate buffer only. The fluorescence unit of each assay, minus that of the blank, was expressed as the relative fluorescence unit for each sample. All numerical data were expressed as the mean \pm SE. ANOVA and Newman-Keuls tests were employed for statistical comparisons.

\section{RESULTS}

The mean total haemocyte count in shrimp before WSSV injection (Time 0 ) was $20.9 \pm 0.7 \times 10^{6} \mathrm{cells} \mathrm{ml}^{-1}$. Following WSSV infection, the count decreased significantly $(\mathrm{p}<0.05)$ from 12 to $36 \mathrm{~h}$ p.i., after which the number stabilized at about $10 \%$ of the initial count (Fig. 1). The count for the control shrimp remained unchanged throughout the study period. By DAPIstaining, condensed and fragmented nuclei were first detected in small numbers of haemocytes in WSSVinfected shrimp at $24 \mathrm{~h}$ p.i. and they increased in numbers significantly thereafter $(p<0.05)$. The percentage of affected nuclei reached about $20 \%$ at $60 \mathrm{~h}$ p.i. while haemocytes in the control group showed no signs of condensation and fragmentation.

By LM of H\&E-stained cephalothorax sections, pathological changes were observed in the tissues originating from embryonic ectoderm and mesoderm, including subcuticular epithelium, gills, haematopoietic tissue, lymphoid organ, haemocytes and the heart. Nuclei were enlarged and sometimes contained eosinophilic (Cowdry A-type) or basophilic inclusions (Fig. 2). The tissue most severely affected was the subcuticular epithelium. The nuclei of some of these infected cells were condensed and fragmented, especially during the later stages of infection.

By fluorescent LM, TUNEL-positive nuclei (green fluorescence) were first observed in the subcuticular epithelium at $6 \mathrm{~h}$ p.i. (Fig. 3), and the number in-

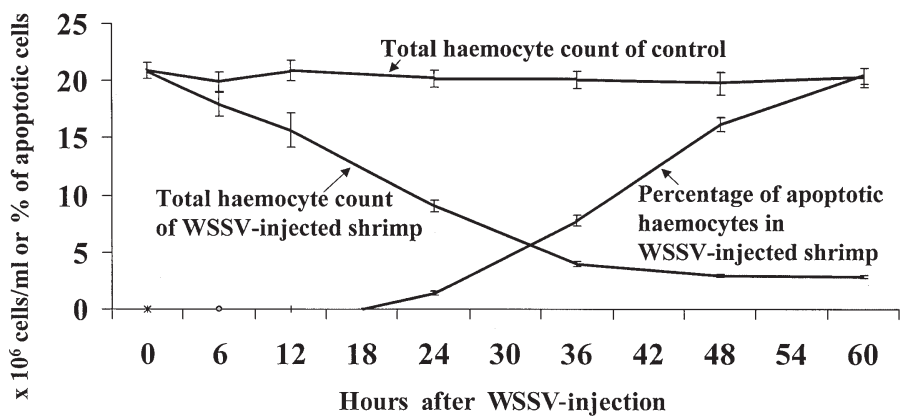

Fig. 1. Penaeus monodon. Total haemocyte counts of control, and WSSV-infected shrimp and percentages of condensed and fragmented nuclei (apoptotic cells) detected by DAPIstaining at different times after WSSV injection. Haemocyte counts from $24 \mathrm{~h}$ post-injection (p.i.) onward were significantly different $(\mathrm{p}<0.01)$ from their respective controls creased significantly $(\mathrm{p}<0.05)$ as the infection progressed (Fig. 4). In the haematopoietic tissue and gills, TUNEL-positive nuclei first appeared at $24 \mathrm{~h}$ p.i. and had increased significantly $(\mathrm{p}<0.05)$ by $36 \mathrm{~h}$ p.i. (Fig. 4). In the gills, green fluorescence was seen in nuclei of both haemocytes and pillar cells. TUNELpositive staining was seen in both enlarged nuclei and in condensed and fragmented nuclei.

TEM revealed that infected shrimp cells showed slightly enlarged nuclei by $12 \mathrm{~h}$ p.i. (Fig. 5A), but WSSV virions were first observed in more enlarged nuclei at $24 \mathrm{~h}$ p.i. (Fig. 5B,C). The enlarged nuclei showed a broad zone of dense, marginated and clumped chromatin surrounded by a less-dense inner zone containing enveloped WSSV particles (Fig. 5B). Some enlarged nuclei at this time and at $36 \mathrm{~h}$ p.i. showed dense marginated chromatin surrounding a central area that contained both rod-shaped and enveloped virus particles (Fig. 5C,D). At $36 \mathrm{~h}$ p.i., some nuclei also exhibited nuclear protrusion of released viral particles (Fig. 5E).

Pathological features characteristic of various stages of apoptosis were observed with TEM (Fig. 6). At $6 \mathrm{~h}$ p.i., the nuclei of some epidermal cells showed either aggregated or fragmented chromatin that developed into dense masses of granules surrounded by a membrane (Fig. 6A). At this time, the cells bulged and budded-off fragments that developed into membranebound nuclear fragments, or 'apoptotic bodies', that were usually observed in intercellular spaces (Figs. 6B \& $7 \mathrm{~A}, \mathrm{D}, \mathrm{E})$. Many apoptotic bodies were observed at $24 \mathrm{~h}$ p.i., and some appeared to be engulfed by neighbouring epithelial cells or by haemocytes (Figs. 7B,C). Surprisingly, no WSSV virions were ever observed in any of the cells undergoing these apoptotic changes.

The caspase-3 enzymatic activity in the subcuticular epithelium increased significantly $(p<0.05)$ in WSSVinfected shrimp $(23.5 \pm 2.1 \mathrm{U}, \mathrm{N}=5)$, compared to that in uninfected control shrimp $(4.1 \pm 0.3 \mathrm{U}, \mathrm{N}=5)$.

\section{DISCUSSION}

A decrease in total haemocyte count after WSSV injection as seen in this study was also observed in Penaeus japonicus by Hennig et al. (1998) (in their study, WSSV are called penaeid rod-shaped DNA virus) and in P. monodon by van de Braak et al. (2002). In contrast, Jiravanichpaisal et al. (2001) found no such decrease following WSSV infection of the freshwater crayfish Pacifastacus leniusculus. The total haemocyte count in P. monodon also decreased rapidly after infection with yellow head virus, and a large fraction of those haemocytes remaining were apoptotic (Khanobdee et al. 2002). In this study, about $20 \%$ of the haemo- 

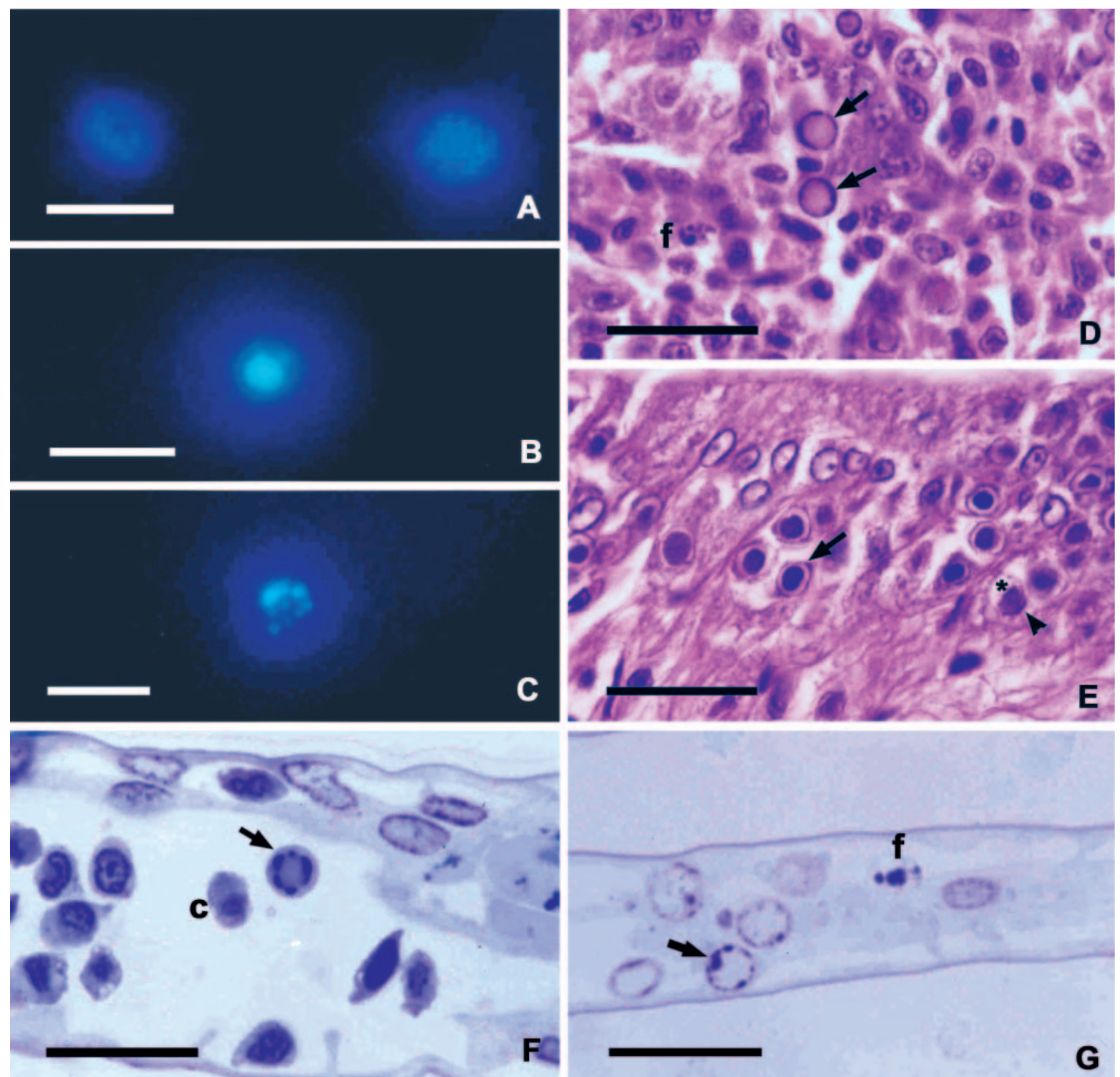

Fig. 2. Penaeus monodon. Fluorescent photomicrographs of (A) normal, (B) condensed and (C) fragmented nuclei of DAPI-stained haemocytes. (D) Haematopoietic lobules of WSSV-infected shrimp at $36 \mathrm{~h} \mathrm{p}$.i. showing enlarged nuclei distributed throughout the lobules (arrows) and a fragmented nucleus (f); H\&E stain. (E) Subcuticular epithelium of WSSV-infected shrimp at $24 \mathrm{~h} \mathrm{p.i.} \mathrm{show-}$ ing nuclei with Cowdry A type inclusions (arrow) and a nucleus with a basophilic inclusion (arrowhead); cytoplasm surrounding the nucleus is lightly stained (*); H\&E stain. (F) Gill filament showing haemocytes with chromatin margination (arrow) and condensed nuclei (c); toluidine-blue stain. (G) Gill filament showing enlarged nuclei (arrow) and fragmented nuclei (f) in pillar cells and haemocytes; toluidine-blue stain. Scale bars $=20 \mu \mathrm{m}$

cytes possessed condensed and fragmented nuclei, as observed using DAPI-staining, suggesting that they were also undergoing apoptosis. TUNEL data suggested that apoptosis also occurred in haematopoietic tissue, and thus the reason for the decrease in haemocytes could be that both haematopoietic tissue (in which haemocytes originate; Hose et al. 1987) and haemo- cytes themselves are target tissues for WSSV infection. However, we found that the number of haemocytes stabilized towards the final stages of infection, indicating that they were still being replaced by new haemocytes from haematopoietic tissue, in which mitotic figures could still be seen. In the early period of viral infection, haemocyte counts decreased dramatically 


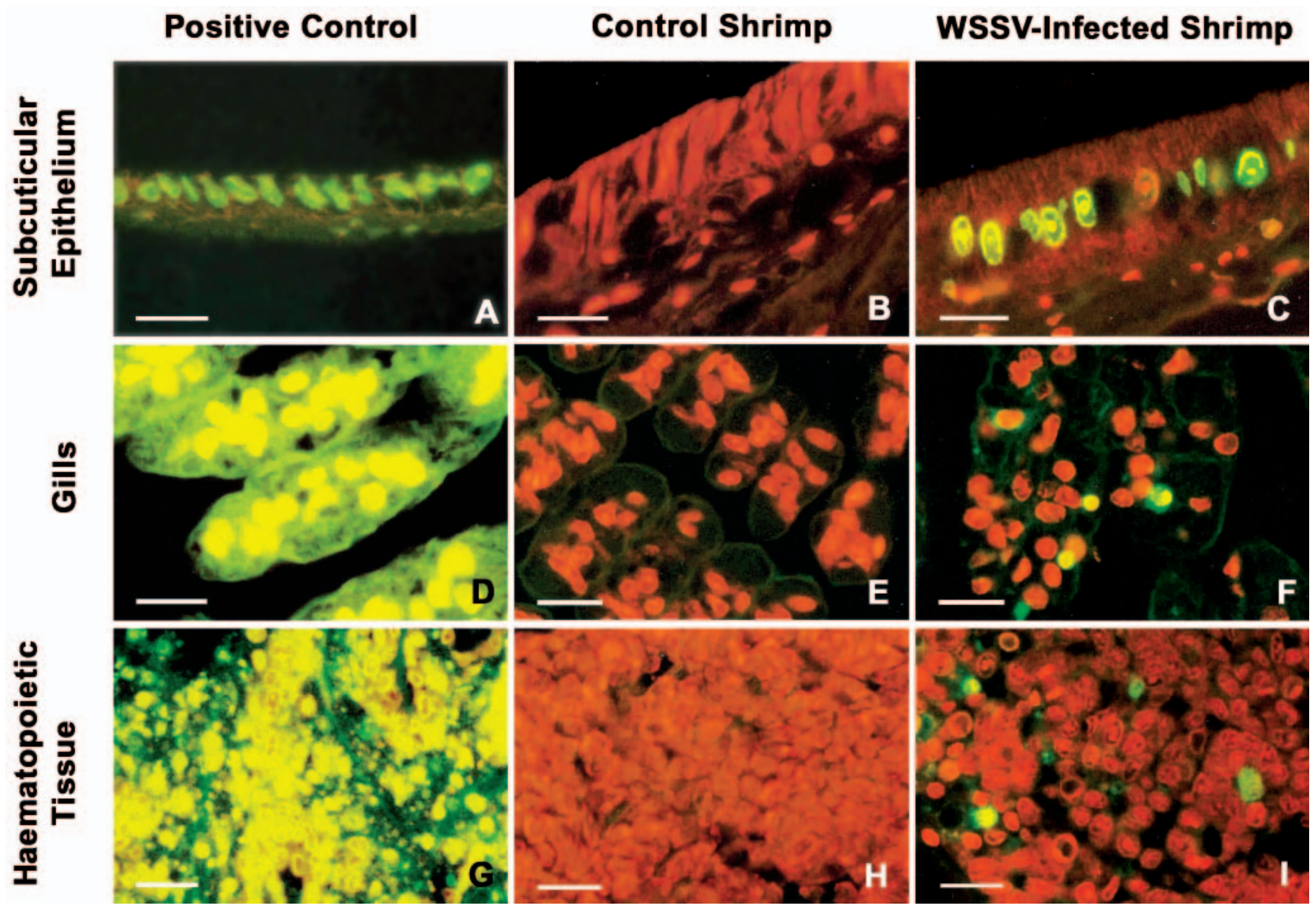

Fig. 3. Penaeus monodon. Fluorescent photomicrographs of TUNEL-positive nuclei in subcuticular epithelium, gills and haematopoietic tissue of WSSV-infected shrimp at $6 \mathrm{~h}$ p.i. Column 1 of the grid comprises 3 DNase I-treated positive control tissues showing all nuclei with green fluorescence. Column 2 grid comprises normal, uninfected tissues of the control shrimp showing only red fluorescence from the counterstain. Column 3 grid comprises tissues of WSSV-infected shrimp showing green fluorescence for TUNEL-positive nuclei. Scale bars $=20 \mu \mathrm{m}$

even though condensed and fragmented nuclei were not observed in smears. Thus, the reason for the drop in the haemocyte count at that time is not clear, but it may have resulted from haemocyte death or migration to tissues, as suggested by van de Braak et al. (2002).

We found TUNEL-positive cells in WSSV-infected Penaeus monodon to be most common in the subcuticular epithelium, followed by the gills and haematopoietic tissue. Wang et al. (2000) also reported WSSVinduced apoptosis in lymphoid organs. Sahtout et al. (2001) found the highest number $(46 \%)$ of TUNELpositive cells in the epithelium of naturally infected $P$. monodon that were 1-step PCR positive for WSSV. In contrast, we found only $10 \%$ TUNEL-positive cells in the subcuticular epithelium at $36 \mathrm{~h}$ p.i. in this study. The difference could be due to differences in the tissue sites studied, the time of analysis after initial infection, the infection dose, or the infection route.

In this study, shrimp were infected experimentally with an unknown quantity of the virus that caused acute infections, whereas the study of Sahtout et al. (2001) involved shrimp that were infected naturally, perhaps with a lower initial dose that took longer to develop into acute infections. With respect to infection

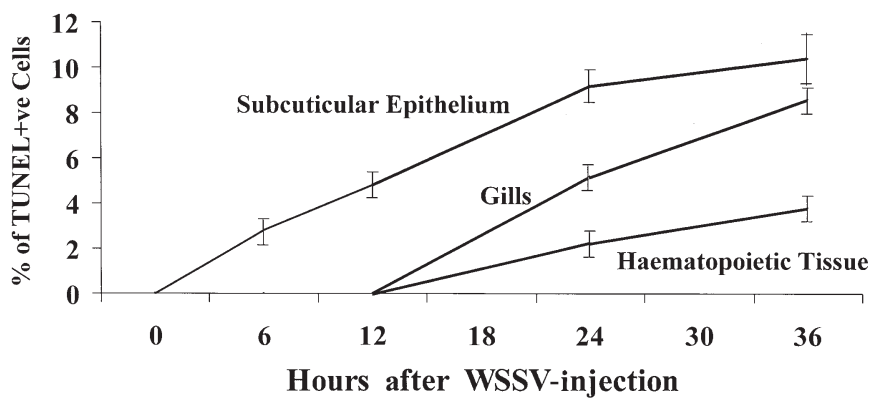

Fig. 4. Penaeus monodon. Percentage (mean \pm SE) of apoptotic cells in subcuticular epithelium, gills and haematopoietic tissue of WSSV-infected shrimp at different times postinjection of WSSV 




Fig. 5. Penaeus monodon. Transmission electron micrographs of subcuticular epithelium of WSSV-injected shrimp. (A) $12 \mathrm{~h}$ p.i.: slightly enlarged nucleus with chromatin margination; (B) 24 h p.i.: enlarged nucleus, showing dense ring-like zone containing marginated chromatin (rz) and central region containing a small number of viral envelopes and particles (vp); (C) 24 h p.i.: epidermal cell with enlarged nucleus showing a dense ring-like zone or marginated chromatin (rz) and central viral envelopes and particles (vp); 36 h p.i.: (D) enlarged nucleus showing thin ring-like zone of marginated chromatin (rz) and many viral particles (vp) in central region; (E) $36 \mathrm{~h}$ p.i.: enlarged nucleus showing high density of viral particles; marginated chromatin is very thin and virions appear to be released from nucleus by extrusion. Scale bars $=150 \mathrm{~nm}$
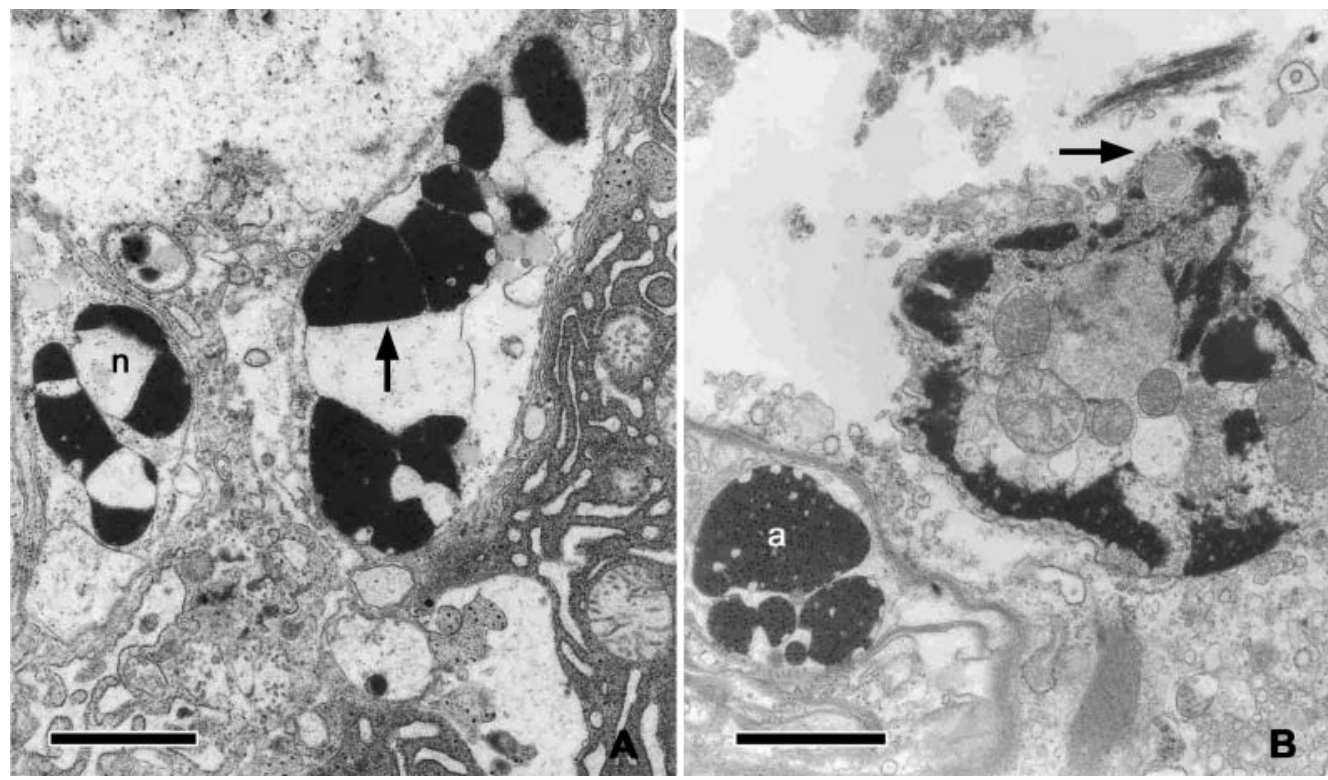

Fig. 6. Penaeus monodon. Transmission electron micrographs of subcuticular epithelium of WSSV-infected shrimp. (A) 6 h p.i.: some apoptotic cells showing sharply delineated masses of condensed chromatin in membrane-enclosed nuclear fragments (arrow) (n: nucleus); (B) $12 \mathrm{~h}$ p.i.: apoptosis in epithelial cells showing multiple nuclear fragments with preservation of organelles, convolution of the cell surface and budding of the cell to produce an apoptotic body (arrow) (a: apoptotic bodies). Scale bars $=150 \mathrm{~nm}$ 


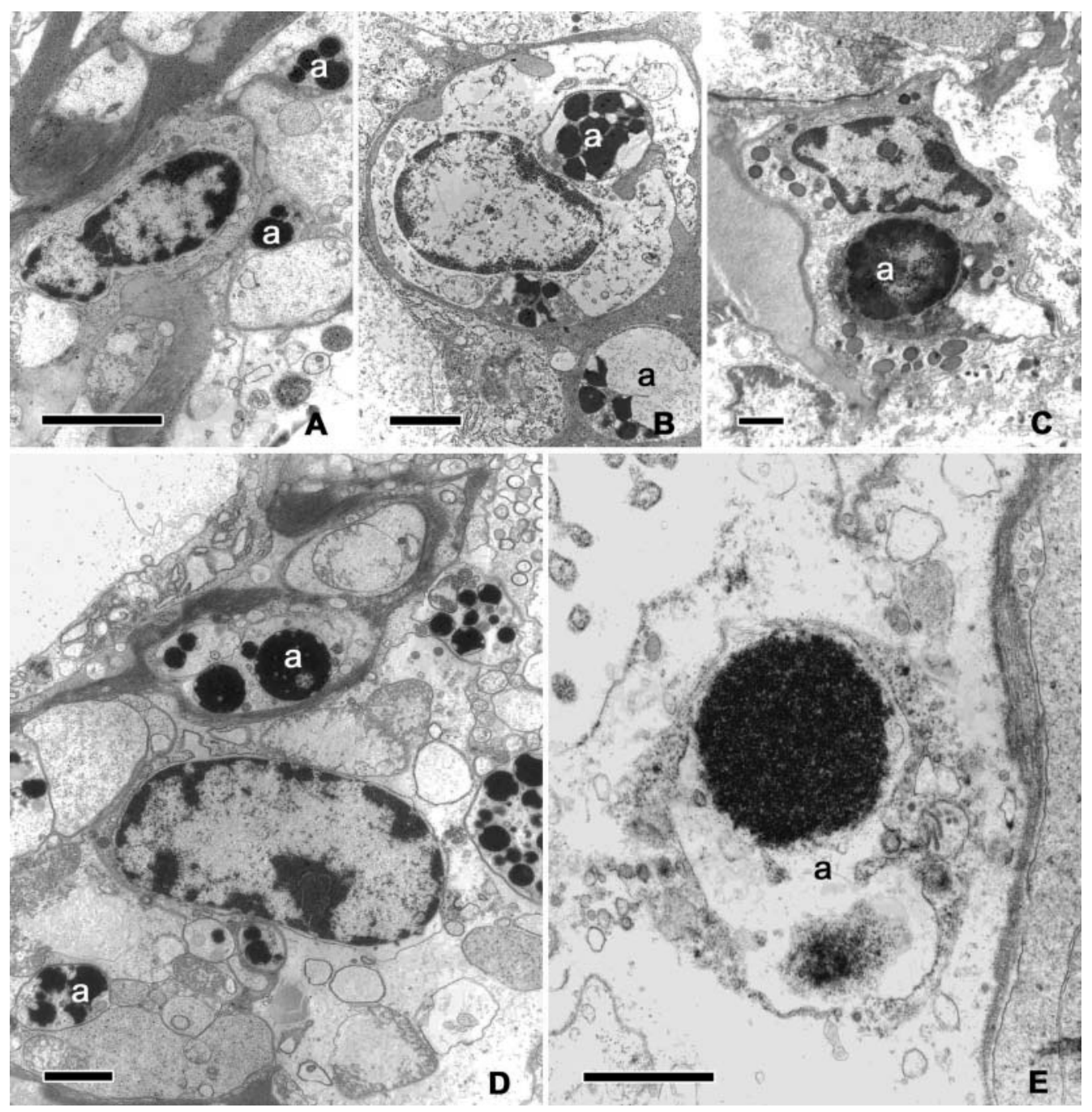

Fig. 7. Penaeus monodon. Transmission electron micrographs of subcuticular epithelium of WSSW-injected shrimp. (A) 12 h p.i.: apoptotic bodies (a) containing nuclear fragments in intercellular spaces. (B) $24 \mathrm{~h}$ p.i.: apoptotic bodies (a) phagocytosed by neighboring epidermal cells. (C) $24 \mathrm{~h}$ p.i.: apoptotic body engulfed by haemocyte. (D) $36 \mathrm{~h}$ i.e.: multiple apoptotic bodies (a) in intercellular spaces in subcuticular epithelium. (E) 36 h p.i.: partly degraded apoptotic body (a) in epithelial cell. Scale bars $=150 \mathrm{~nm}$

dose, it has been reported for neurons (Nicotera et al. 1999) that apoptosis may result in mild infections and necrosis in heavy infections. Other possible complications may occur. For example, recent evidence has revealed that when energy levels are highly compromised, cells triggered for apoptosis die by necrosis instead (Eguchi et al. 1997, Leist et al. 1997). In addition, the virus strain may be important. For example, in Sindbis virus, virulent strains induce more extensive neuronal apoptosis than less virulent strains (Griffin \& Hardwick 1998). Finally, strain variation has also been suggested for WSSV (Sudha et al. 1998), but whether this is related to any difference in virulence that could account for the difference between our results and those of Sahtout et al. (2001) is not yet known.
The occurrence of apoptosis suggested by LM, DAPI-staining and TUNEL-staining was confirmed by TEM. Of particular interest was the fact that cells displaying nuclear condensation and fragmentation characteristic of apoptosis did not contain virions, while those containing WSSV virions were not apoptotic. This strange phenomenon has also been observed in HIV-1 infection, where $\mathrm{CD}_{4}$-T cells infected with HIV-1 do not become apoptotic while uninfected 'bystander' cells close to them do (Kaplan \& Sieg 1998). This phenomenon has been attributed to the viral gp 120 protein, which causes apoptosis in $\mathrm{CD}_{4}$ - $\mathrm{T}$ cells by binding to a $\mathrm{CD}_{4}$ receptor site, while it has been suggested that expression of viral genes such as tat might prevent apoptosis in uninfected cells. However, TAT protein 
secreted by infected cells is believed to either directly enhance apoptosis in uninfected cells or render them hypersensitive to Fas-Fas L-mediated apoptosis (Ensoli et al. 1990, McCloskey et al. 1997). If a similar situation occurs in WSSV-infected shrimp, one could argue that apoptosis is also used in shrimp as a protective response to eliminate viral pathogens. By committing suicide, adjacent uninfected cells would help to limit viral spread.

Many TUNEL-positive nuclei were enlarged and contained WSSV particles as observed by TEM. This indicated that nuclei containing WSSV also underwent DNA fragmentation and this, in turn, suggests that apoptosis also occurred in these WSSV-infected cells. However, these TUNEL-positive cells were atypical of what are normally considered to be apoptotic cells in that the chromatin was not condensed and they did not break up into apoptotic bodies. Thus, either these cells were apoptotic but followed a different degradative course, which would be very interesting indeed, or their DNA became fragmented by some other mechanism, perhaps regulated by viral development and unrelated to apoptosis. One means of resolving this issue might be to use in situ immunochemistry to detect and quantify one or more of the proteins (e.g. active caspase) involved in the apoptosis pathway. However, the increase in caspase-3 activity in WSSVinfected tissue identified here lends support to the argument that apoptosis is involved in the shrimp response to this virus and that it is important in the pathophysiology of WSSV infection.

Acknowledgement. This study was supported by the Institutional Strengthening Program, Faculty of Science, Mahidol University and, in part, by the Thesis Grant, Faculty of Gruadate Studies, Mahidol University.

\section{LITERATURE CITED}

Bradford MM (1976) A rapid and sensitive method for the quantitation of microgram quantities of protein utilizing the principle of protective-dye binding. Anal Biochem $72: 248$

Eguchi Y, Shimizu S, Tsujimdo V (1997) Intracellular ATP levels determine cell death fate by apoptosis or necrosis. Cancer Res 57:1835-1840

Ensoli B, Barillari G, Salahuddin SZ, Gallo RC, Staal FW (1990) TAT protein of HIV-1 stimulates growth of cells derived from Kaposi's sarcoma lesions of AIDS patients. Nature 345:84-86

Flegel T (2001) The shrimp response to viral pathogens. In: Browdy CL, Jory DE (eds) The new wave, Proceedings of the Special Session on Sustainable Shrimp Culture, Aquaculture 2001. The World Aquaculture Society, Baton Rouge, LA

Editorial responsibility: Timothy Flegel,

Bangkok, Thailand
Flegel TW, Pasharawipas T (1998) Active viral accommodation: a new concept for crustacean response to viral pathogens. In: Flegel TW (ed) Advance in shrimp biotechnology. National Center for Genetic Engineering and Biotechnology, Bangkok, p 244-250

Griffin DE, Hardwick JM (1998) Apoptosis in alphavirus encephalitis. Sem Virol 8:481-489

Hennig O, Itami T, Maeda M, Kondo M, Natsukari Y, Takahashi Y (1998) Analyses of hemolymph immunoparameters in kurama shrimp infected with penaeid rod-shaped DNA virus. Fish Pathol 33(4):389-393

Hose JE, Martin GG, Nguyen VA, Lucas J, Rosenstein T (1987) Cytochemical features of shrimp hemocytes. Biol Bull (Woods Hole) 173:178-187

Jiravanichpaisal P, Bangyeekhun E, Soderhall K, Soderhall I (2001) Experimental infection of white spot syndrome virus in freshwater crayfish Pacifastacus leniusculus. Dis Aquat Org 47:151-157

Kaplan D, Sieg S (1998) Role of the Fas/Fas ligand apoptotic pathway in human deficiency virus type 1 disease. J Virol 72:6279-6282

Khanobdee K, Soowannayan C, Flegel TW, Ubol S, Withyachumnarnkul B (2002) Evidence for apoptosis correlated with mortality in the giant black tiger shrimp Penaeus monodon infected with yellow head virus. Dis Aquat Org 48:79-90

Leist M, Single B, Castoldi AF, Khnie S, Nicotera P (1997) Intracellular adenosine triphosphate (ATP) concentration: a switch in the decision between apoptosis and necrosis. J Exp Med 185:1481-1486

Lightner DV (1996) A handbook of pathology and diagnostic procedures for diseases of culture penaeid shrimp. World Aquaculture Society, Baton Rouge, LA

McCloskey TW, Ott M, Tribble E, Khom SA and 5 others (1997) Dual role of HIV Tat in regulation in T cells. J Immunol 158:1014-1019

Nicotera P, Leist M, Manzo L (1999) Neuronal cell death: a demise with different shape. Trends Pharmacol Sci 20: 46-51

Paterson WD, Stewart JE (1974) In vitro phagocytosis of the American lobster (Homarus americanus). J Fish Res Board Can 31:1051-1056

Sahtout A, Hassan MD, Shariff M (2001) DNA fragmentation, an indicator of apoptosis, in cultured black tiger shrimp Penaeus monodon infected with white spot syndrome virus (WSSV). Dis Aquat Org 44:155-159

Sudha PM, Mohan CV, Shanker KM, Hegde A (1998) Relationship between white spot syndrome virus infection and clinical manifestation in Indian cultured penaeid shrimp. Aquaculture 167:95-101

van de Braak CBT, Botterblom MHA, Huisman EA, Rombout JHWM, van der Knaap WPW (2002) Preliminary study on haemocyte response to white spot syndrome virus infection in black tiger shrimp Penaeus monodon. Dis Aquat Org 51:149-155

Wang CH, Yang CY, Lue CH, Kou GH, Lo CF (2000) Ultrastructure of white spot syndrome virus development in primary lymphoid organ cell cultures. Dis Aquat Org 41: 91-104

Wongteerasupya C, Vickers JE, Sriurairatana S, Nash GL and 6 others (1995) A non-occluded, systemic baculovirus that occurs in cells of ectodermal and mesodermal origin and causes high mortality in the black tiger prawn Penaeus monodon. Dis Aquat Org 21:69-77

Submitted: July 17, 2002; Accepted: October 16, 2002

Proofs received from author(s): May 23, 2003 